\title{
O TERNO DE CONGO: UMA FESTA DA INVERSÃO ${ }^{1}$
}

\author{
Ana Claudia Lyra (EHESS/França)
}

O presente artigo tem como objetivo refletir sobre a festa do terno de Congo na cidade de Poço Fundo (MG), festa tomada aqui como um mecanismo de inversão da segregação sócio-espacial característica daquele contexto, fundada em uma estigmatização dos habitantes de um de seus principais bairros, o bairro do Canto. Considerado como o bairro "negro", herança de um passado escrita pelas marcas da escravidão, o Canto é segregado, de um lado, por sua identidade étnica afro-brasileira e, de outro lado, por sua "identidade de pobre" (AUGÉ, 1999:58). Através dos mecanismos sócio-simbólicos de exclusão, o bairro Canto é, assim, posto à parte da sociabilidade no conjunto da cidade. A análise centra-se na festa do terno de Congo, através da qual se dá uma reavaliação, por parte dos habitantes, das fronteiras internas da cidade, que se baseiam, normalmente, numa representação territorial que indica como matriz a fazenda de café, esta última tomada aqui como um padrão de construção, apropriação e vivência dos territórios da cidade.

Palavras-chave: território, identidade e segregação sócio-espacial

\footnotetext{
${ }^{1}$ Trabalho apresentado na $27^{\mathrm{a}}$. Reunião Brasileira de Antropologia, realizada entre os dias 01 e 04 de agosto de 2010 , Belém, Pará, Brasil.
} 
O presente artigo tem como objetivo refletir sobre a festa do terno de Congo na cidade de Poço Fundo (MG), festa tomada aqui como um mecanismo de inversão da segregação sócio-espacial característica daquele contexto, fundada em uma estigmatização dos habitantes de um de seus principais bairros, o bairro do Canto. Considerado como o bairro "negro", herança de um passado escrita pelas marcas da escravidão, o Canto é segregado, de um lado, por sua identidade étnica afro-brasileira e, de outro lado, por sua "identidade de pobre" (AUGÉ, 1999:58). Através dos mecanismos sócio-simbólicos de exclusão, o bairro Canto é, assim, posto à parte da sociabilidade no conjunto da cidade.

A análise centra-se na festa do terno de Congo, através da qual se dá uma reavaliação, por parte dos habitantes, das fronteiras internas da cidade, que se baseiam, normalmente, numa representação territorial que indica como matriz a fazenda de café, esta última tomada aqui como um padrão de construção, apropriação e vivência dos territórios da cidade. Entendendo território como "a porção do espaço apropriado - material ou simbolicamente - por um ou mais grupos sociais que aí encontram fontes de identidade"2 (HOFFMAN, 1995:120), a análise da formação do(s) território(s) da cidade de Poço Fundo toma como base as práticas sociais e espaciais ligadas a uma representação dos grupos que se territorializam na construção de suas identidades. Tais representações se referem a espaços que são, ao mesmo tempo, percebidos e imaginados, isto é, a própria realidade material do espaço é percebida e vivenciada através dos discursos e representações sobre a mesma. Bailly (2006:374), citando Guérin, descreve o conceito de representação em geografia como referente a “ 'criações sociais ou individuais de esquemas pertinentes do real'; esquemas pertinentes pois que eles nos ajudam a compreender a organização do espaço, a julgá-lo e a praticá-lo; criações sociais e individuais uma vez que fazem referência a nossos valores sociais e a nosso potencial pessoal".

Assim, as estratégias dos atores sociais - entendendo estas como parte integrante e fundamental da transformação em suas práticas de utilização do espaço - são orientadas conforme uma representação dual do território da cidade. Dividida em parte alta e parte baixa, a cidade de Poço Fundo desenha fronteiras internas que são percebidas ora por uma divisória física da cidade, como a rua ou a praça, ora por um evento social, como a festa do Congo.

A festa do Congo destaca-se como principal comemoração folclórica e religiosa da cidade. Ela se revela como expressão de "territorialidade", ou seja, meio pelo qual os habitantes se relacionam com a cidade e criam sua identidade através do espaço vivido por eles. Como Silvano (1997:12) afirma : “(...) os membros de uma determinada coletividade possuem repertórios semelhantes de significações, que são

\footnotetext{
${ }^{2}$ A tradução desta e das demais citações feitas no texto são de minha responsabilidade.
} 
reconhecidos como fazendo parte da existência da coletividade. No que diz respeito ao espaço, isso significa que existe um princípio de atribuição de significações ao território que é comum aos membros de uma dada coletividade. Através das representações do espaço, os indivíduos conferem uma especificidade ao seu território e reconhecem uma identidade à sua coletividade, o que significa que se estabelece um laço indissociável entre o sentimento de pertença a uma coletividade e o sentimento de pertença a um território."

A interação social que se forma através do(s) território(s) da cidade forma tipos sociais, cristalizados pela percepção dos habitantes de Poço Fundo. “(...) Os grupos sociais diversificam-se e passam a reconhecer espaços de pertença diferentes (...) O jogo entre o aqui e o além articula a relação com os outros, marca as clivagens que organizam as identidades inclusiva e exclusiva" (SILVANO, 1997: $13)$.

Através dessa vivência territorial, fronteiras sócio-espaciais são formadas e definidas com base em aspectos econômicos, simbólicos e étnicos. Uma das diferenciações que mais se destacam nesta segregação é aquela instalada entre os bairros Canto e Centro, levando a um distanciamento social entre os habitantes de tais bairros. O bairro Canto é relativamente controlado econômica e politicamente pelos habitantes do Centro, que detêm o poder local em sua utilização do espaço urbano. No entanto, é interessante assinalar que a festa do Congo constitui uma inversão provisória e periódica da estrutura sócio-espacial da cidade normalmente calcada sobre uma divisão sócio-econômica e étnica, cuja base ideológica é o modelo da fazenda tradicional de café. Este fenômeno de inversão consistirá no principal objeto deste ensaio.

Portanto, dentro do quadro deste artigo nos limitaremos a uma descrição e análise da festa do Congo e seu mecanismo de subversão territorial face à segregação sócio-espacial de seus habitantes predominante no restante do ano. Do ponto de vista teórico, o trabalho se realiza a partir do diálogo entre Geografia e Antropologia, à luz de algumas categorias respectivas a cada área, como território, segregação sócio-espacial e alteridade cultural, com vistas assim à elaboração de uma perspectiva interdisciplinar (SAUTTER, 2001). O referencial teórico que informa a minha investigação não será apresentado separadamente, mas estará presente na própria discussão etnográfica como lente de interpretação, tal como acontece em trabalhos da tradição antropológica. A pesquisa de campo ateve-se à análise do centro da cidade - núcleo da sua fundação -, ao bairro Canto - antigo bairro da cidade - e a algumas fazendas de café tradicionais do Município.

Os sujeitos que participaram da pesquisa são antigos moradores da cidade (com idades variando entre quarenta e noventa anos), nascidos no Município e que tiveram sua trajetória de vida ligada à história da cidade. Pela inexistência quase total de documentos escritos sobre a fundação da cidade, a fonte etnográfica que mais se destacou e se afirmou como caminho de entrada ao trabalho de campo foi a 
fala dos habitantes ${ }^{3}$, cujo perfil social envolvia, por exemplo, fazendeiros, trabalhadores rurais, profissionais liberais e donas de casa.

A cidade, sendo percebida como "uma pluralidade de experiências, levando a uma dimensão normativa e uma dimensão narrativa dos lugares"4 é traduzida através da narrativa de seus moradores segundo uma percepção do espaço físico, social e simbólico expresso na oposição acima/abaixo, isto é, acima da praça matriz e abaixo desta. Esta oposição revela também uma divisão sócio-econômica dos habitantes, segundo a qual se estabelecem mecanismos de segregação dos habitantes do bairro Canto.

\section{UMA CIDADE REPARTIDA - O FUNCIONAMENTO DA SEGREGAÇÃO}

Localizado ao sul de Minas Gerais, o município de Poço Fundo foi fundado em 1923. Entretanto, seu distrito é anterior, criado em 1870 com o nome de São Francisco de Paula do Machadinho.

Com uma população estimada em 15.916 habitantes (IBGE/2009), o município é formado por 52 bairros rurais, totalizando uma área de $475,4 \mathrm{Km}^{2}$. Cada bairro rural ${ }^{5}$ é constituído por fazendas, sítios e chácaras que são construídos em torno de um núcleo de habitação. Neste encontram-se uma capela, um centro comunitário e uma venda constituindo, assim, um eixo central de relações sociais dos habitantes da área rural. A cidade é formada por dez bairros administrativos, dentre os quais se destacam o Centro, a Vargem e o Canto como bairros principais, descritos neste trabalho como lugares-núcleos e tradicionais de seu território. Nós compreendemos lugares-núcleos ${ }^{6}$ como os lugares pilares da formação do território da cidade, constituindo-se em estruturas da sua formação sócio-espacial. Lugares que desempenham um papel de mediação no processo de tecer os vínculos entre a identidade e o espaço. Assim, os bairros Vargem e Canto formam a parte mais antiga da cidade e a mais precária em estrutura e serviços urbanos. Estes bairros se inserem em uma divisão do território da cidade, expressa em uma oposição que se fará presente na própria percepção simbólica de seu território segundo a divisão parte de cima/parte de baixo. Tal divisão é inscrita fisicamente pelas próprias igrejas da cidade, a saber, a de São Benedito - que centraliza a parte de baixo, sendo vista como a igreja dos "pobres e negros" - e a de São Francisco de Paula (padroeiro oficial da cidade) - que centraliza a parte de cima e agrega os fiéis percebidos na sua identidade de "não pobres e brancos" da cidade.

Tal oposição se faz presente tanto nas práticas sociais, como na esfera da política. Seus dois partidos políticos, representantes do município, foram criados pelos dois fundadores da cidade, a saber, o

\footnotetext{
${ }^{3}$ Ver o artigo de PIVETEAU, J-L, 1995.

${ }^{4}$ LAPLACE-TREYTURE, D., 2001.

${ }^{5}$ Ver o conceito em CANDIDO,1979 e FUKUI, 1979: 69.

${ }^{6}$ No artigo de DEBARDIEUX, 1995:38, o autor afirma: “o lugar é assim uma condição de realização do território pois ele confere uma imagem e pontos de fixação do enraizamento da memória; sendo este também uma vez que permite ao grupo que se ' territorializa' ter uma existência coletiva e locais de vivência”.
} 
Barão de Alfenas e o Capitão Ferreira de Assis, estes fortes opositores e concorrentes ao título exclusivo de fundador pioneiro. Está presente também: nos dois times de futebol, tanto da cidade quanto dos bairros rurais; nas duas escolas de samba, conhecidas como Dois Apitos e Acadêmicos do Morro; e nos dois ternos de Congo que disputavam a festa de São Benedito, o terno de São Benedito e o terno de Nossa Senhora do Rosário. Atualmente, apenas o terno de Congo São Benedito organiza a festa da cidade, o que muito enfraqueceu a representatividade da parte folclórica da festa de São Benedito. Enfim, há uma forte organização dual que indica um modus operandi de territorialização, um estar em sociedade, segundo uma representação que dicotomiza sua experiência territorial por meio das práticas sociais.

Estas expressam-se segundo uma identidade predominantemente rural, a qual confere uma assinatura específica ao território da cidade, representado pelo traço cultural e simbólico da fazenda de café, representante da matriz territorial da região. O rural e o urbano se interpenetram, não ocorrendo uma ruptura de mundos, mas sim uma extensão sócio-simbólica do universo rural ao urbano. Este universo é materializado nos cantos da cidade identificados como os lugares da fronteira entre roça e cidade. Além de eventos de cenários mais agrícolas, como o fumo, são caracterizados pelas saídas dos bairros rurais, marcadas territorialmente pelas chácaras e pelo comércio de "roça", como é usualmente chamado pela população da cidade. Vários aspectos da paisagem ${ }^{7}$ formam verdadeiras instalações do mundo caipira: as cortinas das folhas de fumo dispostas nos andaimes de bambu, as destalas das folhas de fumo por homens e mulheres vindos da roça ou da própria cidade, os rolos de corda ${ }^{8}$ colocados nas calçadas da cidade, se destacando em sua cor, marrom-mel, e em seu cheiro, do fumo já acurado.

Para o poço-fundense, a ação de se territorializar traduz-se em uma (re)interpretação e (re) incorporação da vivência sócio-espacial e cultural da fazenda. A formação das grandes fazendas de café deu-se na primeira metade do séc. XX. Nesta fase, se desenvolveu a base de uma ideologia territorial, legitimada pelo poder político. A formação de uma rede de famílias de fazendeiros, que constituiu o alicerce da organização sócio-espacial, foi expressa pelo poder dos chefes locais e por uma economia agrícola de grandes proprietários de terra, que modelaram os principais elementos da ideologia territorial da cidade de Poço Fundo.

A segregação, que designa uma divisão sócio-espacial dos grupos, surge da ideologia ruralista presente desde a origem da concepção de organização territorial da cidade. Orquestrado por uma política agrária, este fenômeno é conhecido como o mandonismo local (QUEIROZ, 1976). Como apontamos acima, a representação da organização sócio-espacial das grandes fazendas constitui o modelo de formação territorial da cidade. Esta se reproduz segundo os critérios de divisão social e espacial da

\footnotetext{
${ }^{7}$ Entendendo paisagem como o resultado de uma interação que se dá entre o meio e o olhar cultural em questão, Berque assinala: “(...) a paisagem é uma unidade relativa e dinâmica, onde natureza e sociedade, olhar e meio estão em constante interação." Ou seja, a paisagem é vista por um olhar, apreendida por uma consciência, valorizada por uma experiência e julgada por uma estética. BERQUE, 1994: 6.

${ }^{8}$ Cada rolo corresponde aproximadamente a quatro arrobas de fumo, sendo que uma arroba corresponde a $15 \mathrm{kgs}$.
} 
fazenda, que segue o modelo da sociedade escravista do Brasil Colonial. A grande fazenda é percebida como o modelo de organização espacial e territorial de grandes propriedades agrárias, formadas na época colonial brasileira. O coronel (LEAL, 1997: 40) é o planificador e o fundador da cidade, aquele que controla a região e sua inserção no plano nacional.

A cidade é o cenário principal do desenvolvimento político e do crescimento econômico do município. Consequentemente, o retrato da sociedade que o coronel confere à cidade é aquele concebido em sua fazenda. Como assinala Wanderley (2001:35): “em certos casos, como aqueles dos engenhos de açúcar e das fazendas de café, a grande fazenda representava uma concentração demográfica importante". Valverde (1985:41) segue no mesmo sentido: “A fazenda de café clássica era quase uma cidade em miniatura."

A formação e representação sócio-territorial da cidade de Poço Fundo são baseadas sobre o modelo de organização de separação e exclusão de certos grupos sociais em relação a outros. A imagem dos 'negros"9 como escravos, introduzida a partir da relação social escravista estabelecida na grande propriedade fazendária, é perpetuada e (re) significada no relacionamento entre patrão e empregado. Tendo origens escravas, o habitante afro-brasileiro da cidade de Poço Fundo é percebido dentro de um quadro de identidade que Guerin-Pace (2006:299) assinala como le patrimoine identitaire géographique, que o insere territorialmente na cidade de forma segregada e excluída na participação das suas atividades sociais.

A segregação fala de uma exclusão da diferença, de uma rejeição do outro através do território. $\mathrm{O}$ conjunto do tecido social da cidade moderna é ameaçado por este corte que a segregação provoca, expresso nas descontinuidades espaciais. Estas descontinuidades se aguçam pelo crescimento morfológico da cidade segundo uma estrutura que opõe "bairros nobres" e "bairros populares", apoiada sobre uma intensa segmentação de classe social e, igualmente, sobre a fragmentação do espaço urbano. Como afirma Brun (1994:56): “A tentação de reificar a distância social é sempre grande quando esta se inscreve e a princípio se materializa na paisagem urbana, e esta tentação é redobrada assim que esta distância social é 'naturalizada' em diferença étnica ou racial".

Deste contexto surge o bairro Canto, que com sua própria definição aponta para uma separação de seus habitantes face à sua atuação na cidade. O "canto" da cidade é o lugar onde vão se estabelecer os segregados. No dizer de um tradicional fazendeiro, o lugar dos pobres é a "beira" da cidade:

\footnotetext{
${ }^{9}$ Utilizo as denominações "negro" e "preto" como categoria utilizada pelos entrevistados que espelham uma visão da relação identitária eu/outro. A denominação "afro-brasileiro", representativa de uma consciência política urbana e da influência de discursos anti-racistas, está ausente dentre os habitantes da cidade.
} 
"Depois veio qualquer separação com o Canto. O pessoal do Canto já não tinha freqüência lá na repartição mais superior lá de cima e ficou apartado. Hoje é as beiras. As beiras é de pobre.”

(Morador do bairro rural Machadinho Velho, 2008)

Esta descontinuidade espacial é afirmada por uma continuidade histórica na representação das identidades, tanto dos fazendeiros, quanto destes trabalhadores, em sua maioria rurais, vistos como descendentes de escravos das grandes fazendas, que são territorializados segundo esta identidade de "preto" no bairro do Canto. Sendo a fazenda um espaço básico e primeiro da experiência social e pessoal, ela torna-se uma referência de leitura territorial de quaisquer processos de territorialização. Em uma analogia com a estrutura da fazenda, podemos, na cidade, fazer algumas aproximações que exprimem esta projeção imaginada, mas com consequências práticas, do que aqui chamo de território-fazenda.

O Canto, estigmatizado como o "bairro negro", faz oposição com o Centro, percebido como "bairro branco", habitado pela população mais abastada da cidade. Neste, concentram-se os habitantes de poder econômico maior, ao contrário dos habitantes do Canto e da Vargem, que demonstram índices mais baixos de renda familiar. A relação de subordinação também se expressa no fato de que o "canto dos escravos" fornece uma mão-de-obra barata para os trabalhos domésticos das casas da parte alta, principalmente do Centro, assim como para os proprietários agrícolas.

“Eu acho que é um dos lugares de Poço Fundo que mais concentra o preto, né ?”

(Bancário, morador da parte de cima, 2008)

Através destes três principais bairros, o território da cidade é representado simbolicamente pela oposição parte alta/parte baixa, como já exposto acima. A parte alta é a mais desenvolvida e organizada sobre um plano urbano, representada pela praça central, cuja localização marca a divisão do território da cidade. Canto e Vargem estão situados à margem da organização social, formando uma espécie de "franja" da cidade. Um lugar onde ficam expostas as "costuras" do tecido físico e social, como, por exemplo, os tubos de encanamento da rede de esgotos e a ossatura das casas, geralmente com tijolos e cimento à vista. É também onde se localizava o "asilo antigo da cidade", considerado como um lugar "dos esquecidos" e onde se faz fronteira com os vizinhos "muito especiais" do cemitério, segundo a fala de seu João, morador do Canto. O Canto é também visto como o lugar do "bêbado", dos "drogados" e do "mau elemento". 
"O Canto é cheio só de turma que bebe, de cachaceiro, de briga, de turma bagunceira. Aquilo não mudou nada. Já tem assim muita família que hoje, assim.... mas continua a ter uns maus elementos. A maioria é preto."

(Bancário, morador da parte de cima, 2008)

As origens de uma tal percepção encontram-se numa representação das identidades fundadas no território da fazenda, que se expressam na geometria política do território urbano. Este desenha, desde sua fundação, os campos de poder controlados pelos chefes políticos do município de Poço Fundo, fundando, assim, as fronteiras da alteridade da cidade. É, por meio destes chefes políticos, a ideologia territorial da grande fazenda é reproduzida no território da cidade. Uma relação polarizada é formada, expressando, por um lado, a identidade do fazendeiro territorializado na fazenda de café, e, por outro lado, o trabalhador rural, que constrói sua identidade (de origem escrava) na relação de colono a lavrador rural. Desta forma, reifica-se um território da alteridade, pautado na relação dual entre patrões e trabalhadores.

Representando metaforicamente a fazenda, onde a casa-grande é destacada pela sua localização central no núcleo de habitação da fazenda, o Centro é o bairro habitado por uma população majoritariamente branca, formando a classe economicamente mais abastada da cidade. Este território dos "brancos e ricos" tem como marco simbólico o chamado sobrado do Barão, construído inicialmente acima da praça Central. Antiga habitação de um dos chefes políticos e principais fundadores e planejadores da cidade, a casa do Barão transforma-se em uma fronteira que a divide em parte alta e parte baixa. A parte baixa é formada pelos "pobres", localizados nos bairros Vargem e Canto. Este último, por ter o estigma do "bairro preto", é visto nesta perspectiva como correspondente à imagem da "senzala" da grande fazenda; no caso, da grande cidade.

"Estas pessoas mais pobres ficam na beira né? Vinham da fazenda. Naquele tempo eles contava com os pobres na fazenda e não tinha valor não! Os fazendeiros traziam eles no cativeiro, aí vinham pra cá (Canto) e ficavam meio livre."

(Morador do bairro rural Lavrinha, 2008)

"Existe essa separação. Tanto que existia o clube dos ricos que não podia entrar cidadão de cor. Era barrado na porta. Ficava na rua Capitão Ferreira de Assis (parte alta da cidade). Cidadão de cor não entrava, era barrado na porta. Até nós brincávamos se o Pelé vem aqui quero ver quem vai fazer! E o clube dos pretos ficava na praça São Benedito ( parte baixa), o clube Euclide Laudino, que ia o pessoal do Canto e entrava quem quisesse, branco ou preto, não importava." 
Como Freyre (1989: prefácio, $1^{\mathrm{a}}$ ed.) afirma em sua análise sobre da grande fazenda: “A casagrande, completada pela senzala, representa todo um sistema econômico, social, político: de produção (a monocultura latifundiária); de trabalho (a escravidão); de transporte (o carro de boi, o bangüê, a rede, o cavalo); de religião (o catolicismo de família, com capelão subordinado ao pater famílias, culto dos mortos, etc); de vida sexual e de família (o patriarcalismo polígamo); de higiene do corpo e da casa (o "tigre", a touceira de bananeira, o banho de rio, o banho de gamela, o banho de assento, o lava-pés); de política (o compadrismo). Foi ainda fortaleza, banco, cemitério, hospedaria, escola, santa casa de misericórdia amparando os velhos e as viúvas, recolhendo órfãos". A grande fazenda de café é pontuada na pesquisa como matriz territorial do município, prestando-se a modelar diversos contextos sócioespaciais e, em particular, a formação de tipos territoriais: a cidade e os bairros rurais. Augé (1999:54) destaca que: “(...) as concepções do lugar (...) mostram que a forte densidade cultural de certos lugares, assim como o pertencimento que nós sentimos a nosso modo, vêem de dimensões que não dependem diretamente das estruturas materiais urbanas. O sentido de lugar é estreitamente condicionado pela existência de uma troca simbólica e social cujo ele é o suporte.”

No entanto, a despeito do quadro de subordinação econômica e estigmatização social, os habitantes do Canto possuem um momento de "liberdade" de expressão social que os leva a uma condição provisória de destaque na vida cultural da cidade: a conhecida "Congada", festa tradicional da cidade e acontecimento folclórico da cultura brasileira, que ainda sobrevive nas pequenas cidades do interior e que será analisada a seguir.

\section{O INSTRUMENTO DA TRANSGRESSÃO: O CONGO}

Originária da época da escravidão, a festa do Congo no Brasil é conhecida como a "Festa dos Negros". Ela foi trazida pelos escravos africanos através de sua diáspora na América Ibérica, fixando-se desta forma pelo interior do Brasil, onde encontra sua maior propagação. A festa do Congo era organizada no início pelas congregações religiosas e associações laicas formadas pelos negros libertos, que se reuniam em torno de um santo protetor, cuja imagem era colocada sobre um altar diante do qual celebravam o culto. Um dos cultos mais conhecidos era o da confraria Nossa Senhora do Rosário dos Homens Negros.

Atualmente, a festa do Congo acontece nas pequenas cidades tradicionais brasileiras, promovida pela comunidade negra local. Em Poço Fundo, a festa do Congo existe desde 1909. Ela foi fundada por 
Laudino Alves, antigo escravo de São João Del Rey, que se instalou na região de Poço Fundo, enquanto agregado da fazenda de um líder político tradicional da cidade. Em seguida, Laudino Alves se transferiu para o bairro Canto, onde criou suas raízes através da Congada. Na praça São Benedito, que marca a fronteira entre os bairros Canto e Vargem, Laudino Alves fixou uma cruz, fundando os marcos da futura igreja São Benedito.

O território do Canto ganhou assim uma marca de identidade territorial negra, através da construção da igreja e da organização da festa do Congo, realizada pela confraria São Benedito. Outros grupos de Congo se organizaram, à medida que o bairro Canto crescia. Com o aumento da população negra, oriunda, na sua maioria, dos bairros rurais e atraída pelas facilidades que a cidade oferecia, novas quadras de casas no ritmo de formação das famílias que ali se instalaram e se organizaram em pequenas comunidades, formando a base de novos grupos de Congo. Três grupos de Congo se destacaram na cidade, cada um representado por um líder local e por seus "reis". Dois dentre eles são originários do bairro Canto, a saber, o Congo São Benedito e o Congo Santa Efigênia, ambos santos negros. O terceiro, o Congo Nossa Senhora do Rosário, é originário do bairro Santa Helena, cuja formação deu-se posteriormente ao bairro Canto.

Através da organização de grupos de Congo, o bairro Canto constrói sua identidade afrobrasileira, sendo identificado pela população da cidade como o local exclusivo dos "negros da região" que reivindicam suas origens através da Congada. Tal manifestação confere aos habitantes negros da cidade um fator de diferenciação que os coloca em outro nível de comparação e distinção. Não são mais os pobres da cidade, mas sim os negros de origem africana que se distinguem culturalmente, amenizando, assim, o estigma social que carregam e que os enquadra numa classificação depreciativa trazida pelo título de "pobreza". Através da Congada, um sentimento de pertencimento é resgatado, conferindo uma identidade positiva aos habitantes do Canto. Este sentimento leva a uma nova percepção dos Congadeiros quanto à alteridade de seu território. Se, para os habitantes da parte de cima, a Congada reforça a diferença, para os habitantes da parte de baixo, ela é colocada em um contexto outro: não mais o do escravo, que o homogeneiza e o simplifica na sua identidade, mas sim a do africano, que traz na sua identidade um repertório vasto e complexo culturalmente.

A Congada é utilizada pela população local negra da cidade como instrumento da sua alteridade, que a faz ser o "outro" legitimado pela outra cultura, no caso, a africana. Tal mecanismo de fabricação do "si-mesmo como outro" (Ricoeur), através da festa do Congo, confere à população negra da cidade um status cultural que os distancia da classificação sócio-econômica. Cria-se um mecanismo de "desterritorialização" da pobreza baseado neste vínculo de identidade afro-brasileira, que os permite serem percebidos através de um território cultural distinto daquele dos outros habitantes da cidade. Para a 
população desta parte da cidade, sobretudo aquela da parte de cima, tal manifestação cultural, a Congada, é carregada por estigmas raciais que são associados diretamente à questão social.

Geralmente, um habitante negro da cidade é imediatamente identificado como sendo do Canto ou possuidor de laços de parentesco com o bairro. Enquanto preta e pobre, a população do bairro Canto é subjugada e depreciada na sua alteridade, constituindo-se no "outro" rejeitado e estigmatizado pelos significados que foram construídos ao longo de sua trajetória escrava na região. Contudo, a resistência "negra" dos congadeiros oferece um lugar de formação dos líderes da comunidade "negra" e permite a eles exercerem sua sociabilidade longe do olhar dos chefes políticos da cidade. Os habitantes do Canto estabelecem assim os limites de seu território. Tal vínculo cultural que o Congo traz permite a construção e afirmação de um território da alteridade ${ }^{10}$, que é festejado durante a sua celebração. A cada ano tais laços culturais são reafirmados com a troca de seus reis e sua comitiva real, trazendo para o grupo o germe da inversão hierárquica da sociedade local ${ }^{11}$. A festa se caracteriza por um aspecto lúdico popular marcado pelos ritmos dos instrumentos africanos ${ }^{12}$, assim como pelos diferentes movimentos de danças africanas. Estas festas acontecem nas ruas e são acompanhadas de bebidas e pratos típicos africanos, marcando uma inversão temporária da hierarquia local, conduzida por uma liberação de comportamentos admitida no momento da festa. Segundo Luis Antônio, bisneto de seu Laudino:

“A época de seu Laudino, era a época do Canto onde mesmo a polícia não podia entrar! Havia um grupo que mostrava a guarda. Aqui é a nossa parte! É o nosso canto! É o Canto!”

Esta época do senhor Laudino, mitificada pela memória do grupo, é evocada como a época onde o bairro Canto era reconhecido pelas autoridades locais da cidade. Se a cidade não pertence a eles, em contrapartida, o bairro Canto, este canto da cidade, é seu território político e social, organizado pelos grupos de Congo e seus líderes. Forma-se, assim, o território do "outro" em relação à parte de cima da cidade, sendo a festa do Congo um mecanismo de construção e afirmação da identidade territorial.

Atualmente, é o grupo de Congo São Benedito que continua a tradição da família de Laudino Alves. Ele se tornou o Congo do Canto, aquele que guarda a memória de seu fundador e de sua família. Segundo os dizeres de Luiz Antônio:

\footnotetext{
${ }^{10}$ Ver o artigo de LAPLACE-TREYTURE, D.(2001), onde o autor destaca as dimensões narrativas e normativas do lugar na construção da alteridade.

${ }^{11}$ SOUZA, M. de Mello, Reis Negros no Brasil escravista: história da festa de coroação de rei Congo, UFMG, Belo Horizonte, 2002.

${ }^{12}$ LUCAS, G., Os Sons Do Rosário : O Congado Mineiro dos Arturos e Jatobá, UFMG, Belo Horizonte, 2002.
} 
"Nossa tradição segue seu curso. É a família. Se a festa tem lugar amanhã e alguém nasce hoje, no dia seguinte a gente o farda. Se ele morre no Domingo de festa, a gente enterra ele e continua a festa. É a missão."

Enquanto missão e tradição, a festa do Congo se manifesta nas ruas todos os anos, entre os meses de Julho e Agosto. Pode ser dividida em três partes. Uma que se caracteriza na sua tradição eminentemente religiosa, isto é, formada pela procissão, seguida de uma missa. A segunda se traduz na festa propriamente dita, formada pela quermesse e suas barracas de jogos. A terceira parte, de caráter mais tradicional e folclórico, é caracterizada pelos ritos que envolvem a caminhada da congada pela cidade e sua travessia na parte alta.

Cada momento da festa é conduzido por um grupo representativo da cidade. A parte religiosa é comandada pelo pároco da igreja central e sua comitiva de festa. Esta, por sua vez, é formada por habitantes idosos, geralmente mulheres moradoras da parte alta da cidade. A festa é dividida por grupos de casal, moradores da parte de cima, que organizam jogos, ficando as barracas de bebida e comida a cargo dos jovens, moradores também da parte de cima da cidade. No entanto, a Congada, que envolve a travessia na cidade, é formada exclusivamente pelos habitantes do Canto. O Congo passa por uma preparação de seus componentes, envolvendo ensaios dos movimentos e passos ritmados pela música local.

A festa se desenvolve durante uma semana na praça São Benedito, onde é festejada a quermesse e celebrada a missa. Os membros do Congo participam da festa de São Benedito, principalmente no último dia, quando celebram-se a missa e a saída dos santos de seus altares para uma rápida volta em torno da praça. No dia seguinte, o Congo atravessa a cidade, marcando o momento em que os habitantes da parte baixa visitam a parte alta. É o momento da inversão desta fronteira interna da cidade, propriamente falando. É um espaço-tempo onde as normas locais se encontram suspensas, permitindo um tipo de inversão de valores responsáveis pela divisão da cidade. Por exemplo, durante a festa, os habitantes da parte alta ocupam a praça São Benedito, enquanto os habitantes da parte baixa se deslocam em direção à parte alta da cidade.

Durante a quermesse, habitantes da parte alta, geralmente donas-de-casa participantes dos serviços da igreja, montam o stand de jogos, barraca responsável pelo maior volume de arrecadação da festa, instalando-se ao lado da Igreja São Benedito, parte baixa da cidade. Ao mesmo tempo, os participantes do Congo fazem seu percurso, chamado giro, na parte alta da cidade. Durante a quermesse, determinados habitantes desenvolvem um papel importante na construção do território da festa. Os habitantes da parte de cima da cidade, representados por uma classe média alta, geralmente jovens de família tradicional, montam seus stands de jogos e bebidas no espaço central da festa, localizada na parte baixa da cidade. 
Podemos perceber, através das atividades da festa, uma movimentação e uso maior, pelos habitantes da parte de cima da cidade, do território "pobre". O uso momentâneo desta parte da cidade, através da festa enquanto um território, denota uma inversão da ideologia territorial inserindo uma "transgressão" do modelo. Tal inversão é confirmada pelo percurso do "giro" da Congada, através de seus integrantes 'negros' e 'pardos' do Canto, que "invadem" a parte alta da cidade, tradicionalmente percebida como a parte "branca" do território.

A festa do Congo, identificada como uma tradição pela população local, manifesta-se em minha análise como um "evento”. Segundo Sahlins (1990:15), “o evento não é somente um acontecimento no mundo, é a relação entre um acontecimento e um dado sistema simbólico". O Congo traz em si uma carga simbólica da inversão, com seus próprios reis e rainhas, que redimensionam a hierarquia social presente, criando uma situação fictícia de estrutura social local, a qual permite a inversão e transgressão temporária da ideologia territorial da cidade. Enquanto congadeiros, os habitantes da parte de baixo se apossam momentaneamente da parte alta, gerando um deslocamento físico e social da hierarquia local. No momento da passagem dos congadeiros, os habitantes da parte de cima participam como súditos da bandeira de São Benedito, assistindo em suas varandas à passagem do Congo e sua comitiva. Veremos a seguir como se dá o percurso, conhecido como giro, e sua manifestação enquanto dado cultural da tradição local.

\section{O PERCURSO: O “GIRO”}

O giro, organizado pelo terno, nome dado ao grupo do Congo, sai na cidade durante dois dias. No domingo, dia da festa de São Benedito, o qual é coroado pela procissão, sai o terno em direção à parte alta da cidade, atravessando suas principais ruas. No dia seguinte, comemora-se a coroação do rei e da rainha do ano, moradores do Canto. O terno é composto pelos personagens seguintes: o capitão, aquele que conduz o grupo; o contra-mestre, seu ajudante na organização do grupo; as porta-bandeiras, grupo formado por moças; e, fechando o terno, o grupo dos músicos, composto unicamente por homens.

Animados pelo ritmo dos instrumentos de corda e de batuque, instrumentos de percussão, os membros do terno reúnem-se em um terreno vazio de terra batida, chamado "a concentração". O lugar da concentração é marcado simbolicamente pela primeira morada de seu fundador, Laudino Alves. Após sua morte, sua casa foi demolida e seu terreno demarcado como o lugar onde se organiza o Congo e onde se inicia seu desfile. Antes de sua saída oficial, os membros fazem uma reza seguida de uma saudação e reverência à bandeira do Santo, imagem de São Benedito, que é conduzida durante todo o percurso do terno na travessia pela cidade. Cada componente sela seu compromisso com o Santo através de um beijo 
na bandeira, que em troca lhe confere proteção. Tal gesto é conhecido como "pedir a benção ao Santo". Através dela dá-se a passagem dos congadeiros que, enquanto súditos e guardadores da tradição, celebram o dia do santo e sua importância na cidade. O terno abre o desfile subindo as ruas do bairro Canto em direção à parte alta da cidade. Antes de chegar à praça principal, o terno pára em frente ao cemitério, onde é feita uma homenagem aos mortos. O ritmo da música se torna mais lento, marcando um momento de respeito aos antepassados, seguido de uma oração. Logo após, o terno se desloca já num ritmo mais acelerado em direção à praça central, passando antes pela avenida da cidade. A dança e o canto marcam, assim, a passagem do Congo pelas ruas e diferenciam aqueles que participam dela. Estes representam os habitantes da parte baixa da cidade, distinguindo-se dos habitantes da parte alta, que assistem à sua passagem de suas varandas e janelas.

Depois de completar o percurso na cidade, o terno termina sua trajetória na praça São Benedito, onde é esperado pelo padre para dar início à procissão. O terno silencia seus instrumentos de percussão, finalizando o giro pela cidade. Dá-se início, assim, à parte religiosa da festa de São Benedito, onde moradores da parte alta e da parte baixa da cidade se juntam para a procissão. Estátuas de São Benedito e de Santa Efigênia saem carregadas da Igreja São Benedito e fazem um pequeno giro em torno da praça São Benedito, finalizando com o retorno dos Santos à igreja, onde é celebrada a missa que encerra a semana de comemoração da festa.

\section{CONCLUSÃO}

A festa do Congo se expressa como um mecanismo de territorialidade de uma identidade marcada pelo passado histórico da escravidão, que funda uma relação de alteridade.

A dualidade, que é elemento formador da vivência territorial e convivência pessoal dos habitantes da cidade, expressa reiteradamente nas suas representações do território e práticas sociais. O duo está sempre presente no olhar do poço-fundense, que territorializa sua alteridade e se socializa nestas bases. O eu e o outro são espacializados em uma identidade binária, que se expressa na organização territorial da cidade em parte de cima / parte de baixo. Esta representação desenvolve um importante papel na forma de se territorializar e de se formar as práticas sociais que reproduzem as fronteiras internas da cidade, levando à segregação social.

Através da inversão do modelo parte de cima/parte de baixo, calcada numa ideologia territorial baseada na representação da tradicional fazenda de café da região, os significados do território da cidade são suspensos e mobilizados segundo uma inversão da ordem sócio-territorial, que o próprio rito permite. 
Esta inversão momentânea da divisão do espaço da cidade remete a um dos volets da "cidade dupla", ou da "cidade bis", que Auge (1999:16) apresenta na sua análise:

«la ville bis est une synthèse de l"expérience de la citadinité, plus fluide mais aussi plus réelle que les villes elles-mêmes dans leurs formes et leurs institutions. Autrement dit, la perspective situationnelle nous rapproche de la culture citadine et des stratégies proliférantes et invisibles de reinversion de la ville."

Assim, tal como uma metáfora da revelação fotográfica, a cidade apresenta no seu quotidiano o lado "positivo" da sua imagem, revelando cores institucionais, nomes sociais e uma ideologia territorial. Mas o fenômeno da inversão simbólica da festa revela também o lado "negativo" da imagem da cidade, suspendendo provisoriamente a exclusão sócio-espacial embutida naquela ideologia. A festa do Congo é apresentada como o "negativo" da fotografia, que revela o outro lado, um outro modo de interpretação da cidade, segundo os jogos de inversão das normas a partir de uma prática e de estratégias dos atores, conforme seus papéis sociais. Pretos, excluídos da cidade, são transformados em reis e rainhas, coroados pelo rito em nome de uma tradição cultural que os destaca em papéis de comando. Trata-se de momentos de suspensão da ordem, inversão dos significados, troca momentânea da visibilidade social, comandados pela dramatização do grupo social que a festa do Congo estabelece. 


\section{BIBLIOGRAFIA}

AUGE, M., L'invention de la ville, banlieues, townships, invasions, favelas, Ed. Des Archives Contemporaines, Paris, 1999.

BAILLY, A ., Les représentations en géographie, Annales de Géographie, nº 621 , 2001.

BERQUE, Augustin (org.), "Cinq prpositions pour une théorie du paysage”, Champ Vallon, 1994, Paris.

CANDIDO, Antônio- Os Parceiros do Rio Bonito, Livraria Duas Cidades, São Paulo, 1979

DEBARDIEUX, B. “Le lieu, le territoire et trois figures de réthorique”, in, L’Espace Géographique,, n.2, 1995.

FUKUI, L. F. G. Sertão e Bairro Rural. Ática, São Paulo, 1979.

GUÉRIN-PACE, F., “Sentiment d'appartenance et territoires identitaires”, in, L'Espace Géographique, n.4, 2006.

HOFFMAN, Odile, "Les points d'ancrage d'un territoire à la dérive au Mexique”, in CLAVAL, Paul \& SINGARAVELOU (direct.), Ethnogéographies, L’Harmattan, Paris, 1995.

LAPLACE-TREYTURE, D., "Dire l'atérité : les discours géographiques à l'épreuve de Los Angeles", in, $\mathrm{n}^{\circ} 107,2001$.

LEAL, V., Coronelismo, enxada e voto, Rio de Janeiro, Nova Fronteira, 1997.

PIVETEAU, J-L, “Le territoire est-il un lieu de mémoire?”, in, L’Espace Géographique, n.2, 1995.

QUEIROZ, M.I. P, O mandonismo local na vida política brasileira e outros ensaios, Alfa-Ômega, São Paulo, 1976.

SAHLINS, M., Ilhas de História, Jorge Zahar, Rio de Janeiro, 1990.

SAUTTER, Gilles, “Géographie et anthropologie”, Annales de Géographie, n 621, 2001, Paris.

SILVANO, F. Territórios da Identidade, Oeiras, Celia, 1997.

VALVERDE, O. Estudos de geografia agrária brasileira, Vozes, Petrópolis, 1985. 
WANDERLEY, M. de N.B. "Regards sur le rural brésilien”, in Zanoni, M. e Lamarche, H. (coord.), Agriculture et ruralité au Brésil, Karthala, Paris, 2001. 